\title{
FRÖCCSÖNTŐ SZERSZÁMOK AKTÍV RÉSZEINEK KORSZERÛ́ TECHNOLÓGIÁJÁNAK TANULMÁNYOZÁSA
}

\section{STUDY OF ADVANCED MANUFACTURING TECHNOLOGIES FOR ACTIVE PARTS OF INJECTION MOLDS}

\author{
Soós Noémi Rita ${ }^{1}$, Soós Ödön János ${ }^{2}$ \\ ${ }^{1}$ Kolozsvári Müszaki Egyetem, Gépgyártástechnológia tanszék, 400641, Románia, \\ Kolozsvár, B-dul Muncii, 103-105; Telefon: +40-745-858894, levelezési cím: \\ noemi_soos@yahoo.com \\ ${ }^{2}$ Kolozsvári Müszaki Egyetem, Gépgyártástechnológia tanszék, 400641, Románia, \\ Kolozsvár, B-dul Muncii, 103-105; Telefon: +40-742-700763, levelezési cím: \\ soosodon@yahoo.com
}

\begin{abstract}
The main objective of this paper is to show the advantages of advanced manufacturing, such as high speed machining (HSM), for the active plates of injection molds. The goal of the experiment is to push the machine and the tools to the limit without reducing the surface quality of the manufactured part. The parts that are machined in this experiment are the active components of bucket injection mold. The mold core and nest is composed from several plates that have to form a whole when mounted together.
\end{abstract}

Keywords: CNC, injection mold, HSM

\section{Összefoglalás}

A dolgozat célja, hogy bemutassa a korszerü gyártástechnológia előnyeit, mint például a nagy sebességü megmunkálást (High Speed Machining- HSM) a fröccsöntő öntőformák aktív elemei számára. A kísérlet célja, hogy a megmunkálásnál használt gép és szerszámok kapacitását teljesen kihasználjuk anélkül, hogy csökkentené a gyártott rész felületi minőségét. A kísérletben megmunkált alkatrészek egy vödör fröccsöntő szerszám aktív összetevői. A fröccsöntő szerszám aktív részei, a mag és a fészek, több olyan részböl áll, amelyek összeszerelt állapotban egészet alkotnak.

Kulcsszavak: CNC, fröccsöntö szerszám, HSM

\section{Bevezetés}

A fejlett gyártási technológiákat egyre gyakrabban használják a CAM szoftverek előnyei miatt. Ezzel az eszközzel a gyártók hihetetlen eredményeket érhetnek el a megmunkálási folyamatban. A szerszám élettartama meghosszabbítható és a gyártási idő jelentősen csökkenthető. Ez a fejlett technológia a nagysebességü megmunkálás (HSM). A nagysebességü megmunkálás egy olyan fejlett gyártási technológia, amely nagy hatással van a feldolgozóiparra. Ennek a megmunkálási technológiának több definíciója is van a szakirodalomban. Az egyik meghatározás az, hogy ez az eljárás „megmunkálást tesz lehetővé, jelentősen nagyobb vágási sebességgel és előtolással, 
mint a hagyományos megmunkálásnál” [1]. A nagysebességü megmunkálás folyamata széles körben alkalmazható, mint például a fröccsöntő szerszámgyártásnál, a repülögépiparban, és így tovább. Ezen technológia jelentősége a termelésben az új gépek és szerszámfejlesztés óta nőtt. A szerszámok és gépek evolúciója lehetővé teszi számunkra, hogy ezt a technológiát alkalmazzuk, egyrészt a folyamatidő csökkentésére, másrészt a gyártott termékek felületminőségének javítására. A felületi minőség fő jelzője a felületi érdesség, amely a méretszabályozással együtt a legmeghatározóbb követelmények.

\section{Kísérleti adatok és beállítások}

A kísérlethez használt gép egy Haas VF-3 CNC függőleges megmunkáló központ, amelynek az $\mathrm{X}$ tengelyen a mozgása $1016 \mathrm{~mm}$, az Y tengelyen $508 \mathrm{~mm}$, a $\mathrm{Z}$ tengelyen pedig $635 \mathrm{~mm}$. A megmunkáló központ 22,4 kW-os fỏorsóval van ellátva, beépített meghajtással és egy 3/4-es lóerős hütörendszerrel. Ráadásul egy vezeték nélküli intuitív próbarendszerrel (ezzel méreteket mérhetünk és beállíthatjuk a gyártási részt), valamint egy nagysebességü megmunkálási integrált szoftver opcióval is rendelkezik, amely lehetővé teszi a gép számára, hogy elöre olvassa a G-kódot és optimalizálja a gyorsulást és lassulást a programozott ívszegmenseken, így jobb felületminőséget eredményeznek.

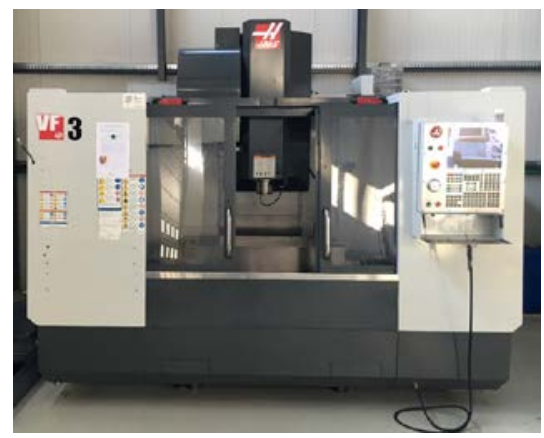

1. ábra. HAAS VF-3 CNC gép
A kísérlethez használt szerszámok kemény anyagok eltávolítására és a 3D felületek finom vágására a Ceratizit és a Widea cégtől származnak. A gyártási folyamat során egy 10 mm-es szabálytalan csavart vágóéllel rendelkező ujjmarót használtunk a lap nagyolásához, mely elősegítette a megnövelt anyageltávolítást és egy gömbvégü marót a fröccsöntő szerszám 3D-s felületeinek simításához. A csavart horonyos maró biztosítja a sima vágást és ugyanakkor az alacsony rezgést és zajt, még akkor is, ha jelentős vágási mélységet használunk. A fokozatosan növekvő csavarvonal emelkedési szögnek köszönhetően a maró magjának átmérője alkalmas a forgácseltávolítás optimizálására.
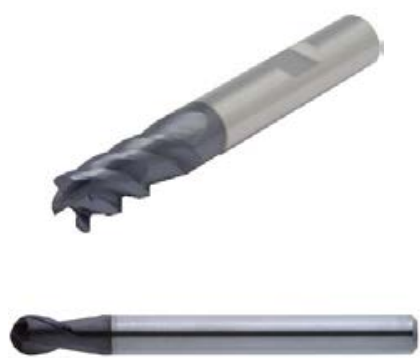

2. ábra. A kísérletben használt maróeszközök [2]
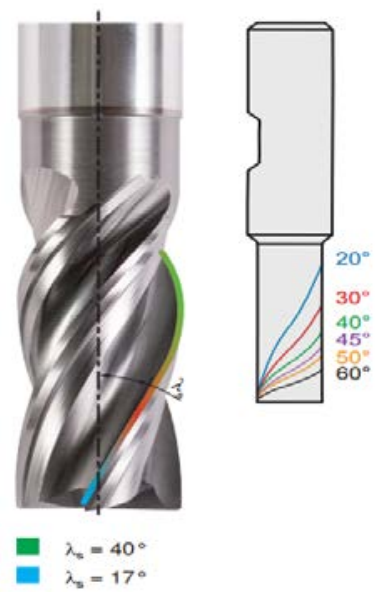

3. ábra. A megmunkálásnál használt maró [2] 
- a 10 mm-es ujjmaró kezdeti paraméterei:

$$
\begin{aligned}
& \mathrm{v}_{\mathrm{c}}=100 \sim 130 \quad[\mathrm{~m} / \text { perc }] \text { és } \mathrm{f}_{\mathrm{z}}=0.05 \\
& {[\mathrm{~mm} / \mathrm{fog}]} \\
& \mathrm{a}_{\mathrm{e} \max }=1 * \mathrm{~d}[\mathrm{~mm}] \\
& \mathrm{a}_{\mathrm{p} \max }=2 * \mathrm{~d}[\mathrm{~mm}] \\
& \mathrm{n}=\left(\mathrm{v}_{\mathrm{c}} * 1000\right) /(\mathrm{d} * \pi)[\text { fordulat/perc }] \\
& \mathrm{f}=\mathrm{n}^{*} \mathrm{f}_{\mathrm{z}} * \mathrm{z}[\mathrm{mm} / \text { perc }] \\
& \mathrm{n}_{\min }=100000 / 10 * \pi=3184 \text { fordulat/perc }
\end{aligned}
$$

$\mathrm{n}_{\max }=130000 / 10 * \pi=4140$ fordulat/perc

$\mathrm{f}_{\min }=3184 * 0.07 * 4=636 \mathrm{~mm} /$ perc

$\mathrm{f}_{\max }=4140 * 0.05 * 4=828 \mathrm{~mm} /$ perc

$\mathrm{a}_{\mathrm{e}}=10 \mathrm{~mm}$

$\mathrm{a}_{\mathrm{p}}=10 \mathrm{~mm}$

-a 10 mm-es gömbvégü maró kezdeti paraméterei:

$\mathrm{v}_{\mathrm{C}}=115 \sim 135 \quad[\mathrm{~m} /$ perc $]$ és $\mathrm{f}_{\mathrm{z}}=0.03$ [mm/fog]

$\mathrm{a}_{\mathrm{e} \max }=1 * \mathrm{~d}[\mathrm{~mm}]$

$\mathrm{a}_{\mathrm{p} \max }=0.5 * \mathrm{~d}[\mathrm{~mm}]$

$\mathrm{n}_{\min }=115000 / 10 * \pi=3660$ fordulat/perc

$\mathrm{n}_{\max }=180000 / 10 * \pi=4297$ fordulat/perc

$\mathrm{f}_{\min }=3660 * 0.03 * 2=219.6 \mathrm{~mm} /$ perc

$\mathrm{f}_{\max }=5729 * 0.03 * 2=343.7 \mathrm{~mm} /$ perc

$\mathrm{a}_{\mathrm{e}}=10 \mathrm{~mm}$

$\mathrm{a}_{\mathrm{p}}=5 \mathrm{~mm}$

\subsection{A vödör forma aktív részeinek anyagszerkezete és felépítése}

$\mathrm{Az}$ említett öntőforma aktív részeihez használt anyag az 1.2311/ 40CrMnMo7-es acél. Ez egy ötvözött acélszerkezet, amely általában előedzett állapotban kapható. Az 1.2311 acél kiváló polírozó tulajdonsággal rendelkezik, ezért gyakran használják müanyag fröccsöntő szerszámok felépítésénél. Kiváló kopásállósággal rendelkezik, amely lehetővé teszi a mủanyag alkatrészek nagy elöállítását a fröccsöntési folyamat során. Ezt az anyagot szükség esetén lehet edzeni (55 59HRc) vagy nikkelezni (650 HV ami egyenértékü $58 \mathrm{HRc}$ ).
1. táblázat. A megmunkálásnál használt anyag kémiai összetevői [3]

\begin{tabular}{|c|c|c|c|}
\hline Karbon & $\begin{array}{c}0.35- \\
0.45 \%\end{array}$ & Króm & $\begin{array}{c}1.80- \\
2.10 \%\end{array}$ \\
\hline Mangán & $1.30-$ & Molibdén & $0.15-$ \\
& $1.60 \%$ & & $0.25 \%$ \\
\hline Kén & $0.03 \%$ & Szilikon & $0.20-$ \\
& $\max$ & & $0.40 \%$ \\
\hline Foszfor & $0.03 \%$ & & \\
& $\max$ & & \\
\hline
\end{tabular}

Az anyag kémiai tulajdonságainak köszönhetően viszonylag könnyü megmunkálni, de ha a gyártásnál használt stratégia nem megfelelő, akkor a szerszám kopása gyorsan növekszik, ami hatással van a megmunkált rész felületi minőségére.

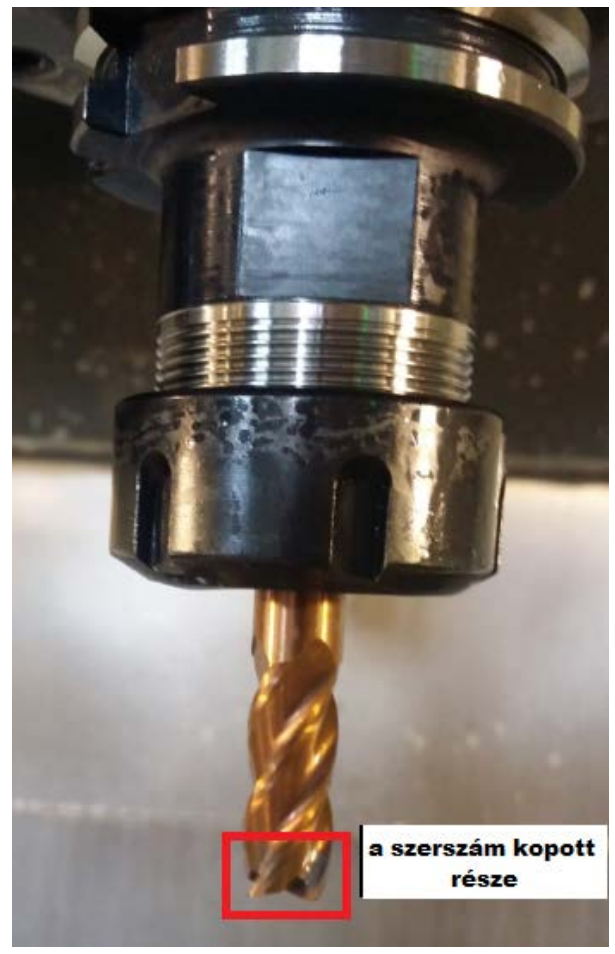

4. ábra. A maró kopott része a nem megfelelö stratégia és megmunkálási sebességek használatának következtében

A vödör forma aktív részeinek szerkezete az 5. ábrán látható. 


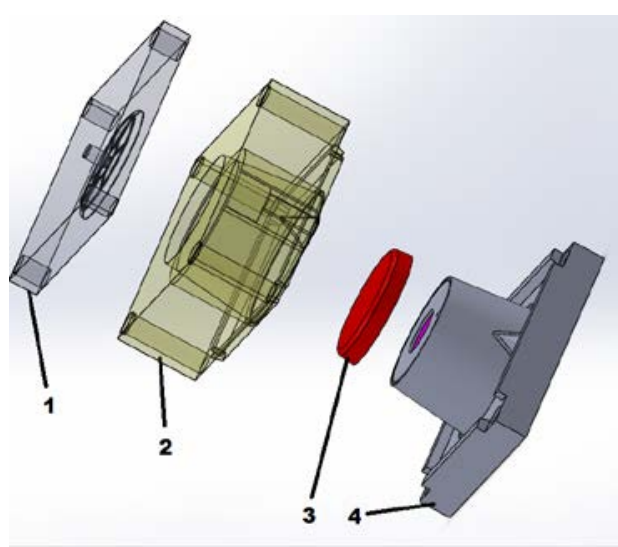

5. ábra. A vödör forma aktív részei

A vödör formája négy egyedi részből áll. $\mathrm{Az}$ 5. ábrán látható 1 és 2 részek az öntőforma fészkét és a fröccsöntés után a vödör külső részét képezik. A 3. és 4. részek a szerszám magját képezik, amely a fröccsöntött termék belsejét materializálja. A részek megmunkálását külön-külön végezzük el az öntőforma mérete miatt, míg a simítási müveleteket részben összeszerelt állapotban, az 1 . és 2 . részeket egyben és a 3., 4. részeket szintén egybeszerelve.

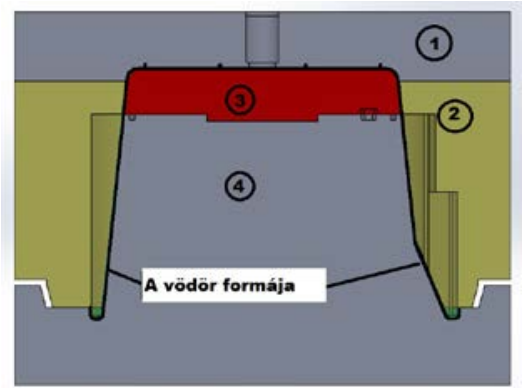

6. ábra. A vödör forma aktív részei összeszerelt állapotban

A vödör formájának kialakítása lehetővé teszi a darab evakuálását a meredek szögek és a pneumatikus és hidraulikus hajtásokkal ellátott kidobórendszer miatt. A pneumatikus hajtás levetkőzteti a vödröt a fröccsöntő forma felületéről, míg a hidraulikus dugatytyú kilöki azt.

\section{Kísérleti eredmények}

A nagysebességü megmunkálási technológia tanulmányozásához egy CAM szoftvert alkalmaztunk, nagysebességü stratégiák és adekvát G-kódot generáló rendszer kapacitásával. Erre a célra a Mastercamot, a globális vezető CAM szoftvert választottuk, amely integrálta a HSM stratégiákat a dinamikus marással kombinálva. Ez lehetővé teszi számunkra, hogy a legkorszerübb programozást alkalmazzuk és példázzuk a stratégiák előnyeit.

Kezdetben a fröccsöntő forma 3. aktív részét munkáltuk meg (5. és 6. ábra). $\mathrm{Az}$ alkalmazott stratégia és paraméterek a következők:

- stratégia (HSM): nagysebességü felületi nagyolás;

- kezdeti orsósebesség: 3200 fordulat/perc;

- előtolás: $600 \mathrm{~mm} /$ perc;

- mélység: 10 mm, pályára állási mód spirális interpoláció;

- lépték: 5 mm;

-becsült ciklusidő: 1 óra 10 perc.

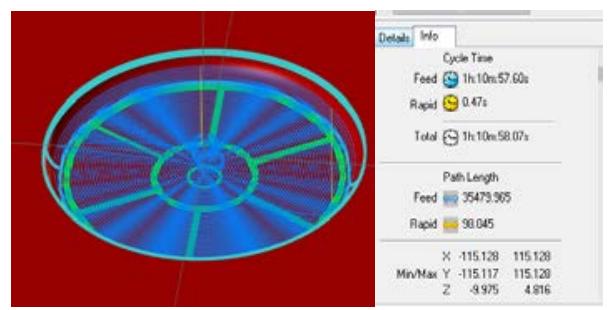

7. ábra. A maró mozgási pályája a használt HSM stratégiánál és a becsült ciklusido”

Az alacsony orsóterhelés miatt a megmunkálás megkezdése után növeltük a marószerszám előtolási sebességét, hogy megfigyeljük milyen hatással lesz a megmunkált felületre és a marószerszámra. A müvelet végső határértékei 3520 fordulat/perc orsó fordulatszám és 2040 mm/perc előtolási sebesség a 8. ábrán láthatók. Ha az előtolási sebességet 340\%-al és az orsó fordulatszámát 110\%-al növeltük, az orsó terhelése 
még mindig alacsony volt, körülbelül 16\% tömör anyagban. Ez azért volt lehetséges, mert a HSM szerszámpálya csökkentette az orsóterhelést és növelte a szerszám élettartamát. Ezzel a stratégiával a becsült 70 perces megmunkálási időt 18 percre csökkentettük.

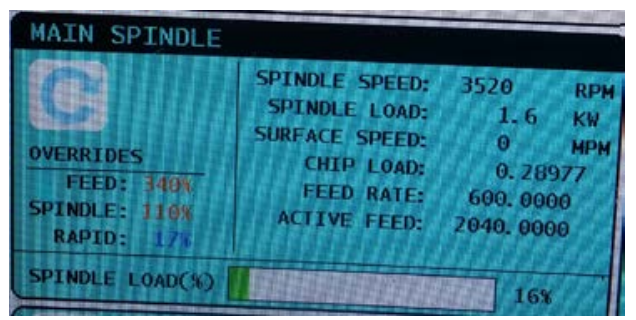

8. ábra. A kiindulási marási paraméterek felülírása

A megmunkálási folyamat befejezése után ellenőriztük az ujjmarót és a felület minőségét. Az ujjmaró még újnak látszott, a megmunkált felület pedig kiváló volt a nagyolási stratégia számára.

A nagyolás után 2D-s nagysebességü és nagysebességü „flowline” stratégiát alkalmaztunk, amivel nagyon sima felületet értünk el.

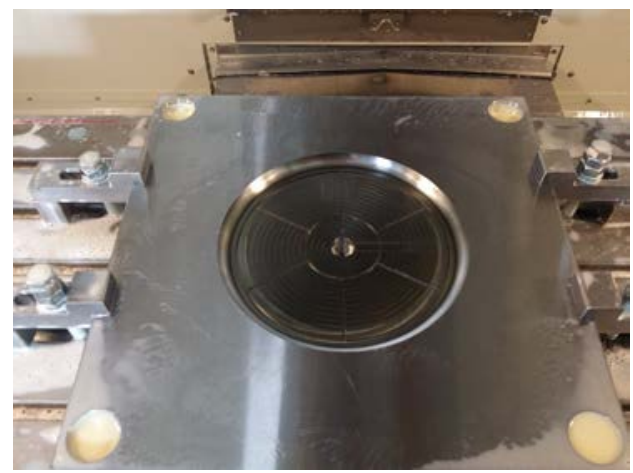

9. ábra. 3-as aktív formalap simítás után

A megmunkált felület minősége az elvárásoknak megfelelt, ebben az esetben befejezett résznek számított, nem volt szükség későbbi polírozási müveletre. Az elért felületi érdesség 0.4-0.8 $\mu \mathrm{m}$ között volt.
A 4-es aktív formalap esetében ugyanazt a simítási HSM stratégiát alkalmaztuk, 0.5 mm-es vágási szélességgel és 0.3 mm-es vágási mélységgel, hogy finom felületet érjünk el. A marás mélysége spirálmódban készült az anyag folyamatos eltávolításával. Ez csökkentett ciklusidőt és jó minőségü felületet biztosított a megmunkált résznek. Ebben az esetben is a becsült elméleti ciklusidőt 45\%-al csökkentettük, miután a határokig növeltük a sebességet és az előtolást. Az alacsony orsóterhelés és a jó forgácsevakuálásnak köszönhetően a marószerszám tökéletes állapotban volt a kész müvelet után.

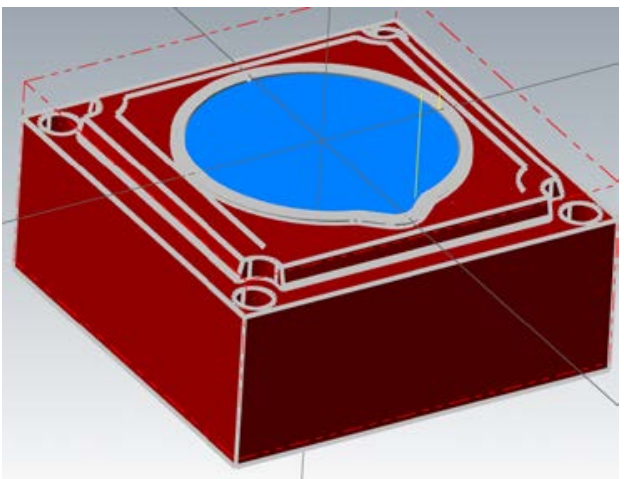

10. ábra. „Surface flowline” stratégia Mastercam szoftverben

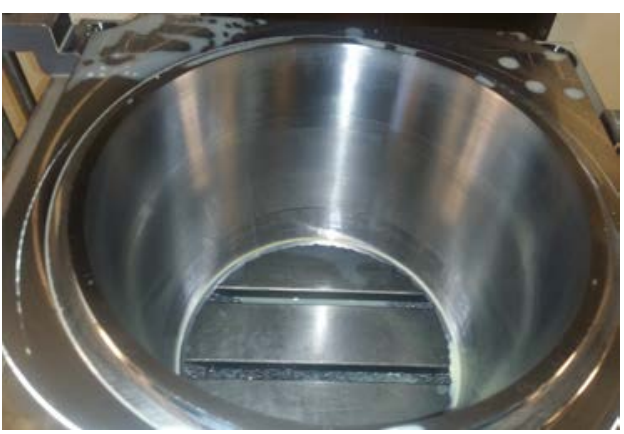

10. ábra. Simított 4-es aktív formalap

Mivel a 4-es formalap vastagsága 245 mm volt, a megmunkálási folyamat során kis rezgések jelentek meg. Még ezen rezgé- 
sek esetén is a felületi minőség $\mathrm{Ra}=1-1.6$ $\mu \mathrm{m}$ között volt, de $0.8 \mu \mathrm{m}$ alatt kellett lennie ahhoz, hogy a termék megfelelö legyen az ügyfél számára. A megmunkálást egy polírozási művelet követte, speciális csiszolópapírral és finom csiszolópasztával. A kézzel végzett rövid polírozás után a felületi minőség a kívánt paraméterekben volt.

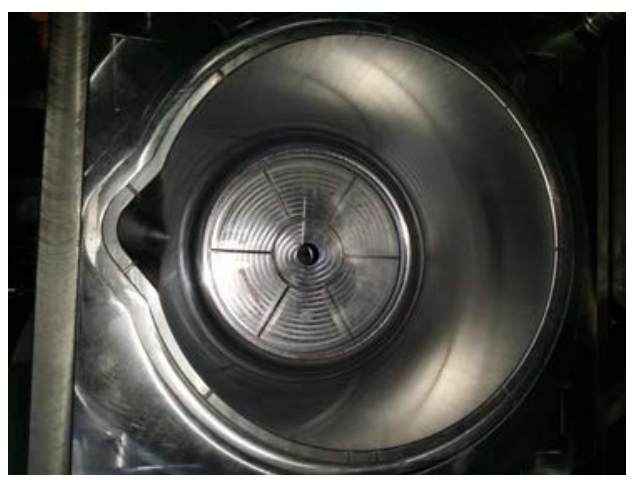

11. ábra. Összeszerelt 3-as és 4-es formalap

Ugyanazokat a nagysebességű megmunkálási stratégiákat alkalmaztuk a vödörforma 1 és 2 aktív részein is. Hasonló eredményeket figyeltünk meg a ciklusidöben, a szerszámterhelés csökkenésében és a jó felületi minőségben.

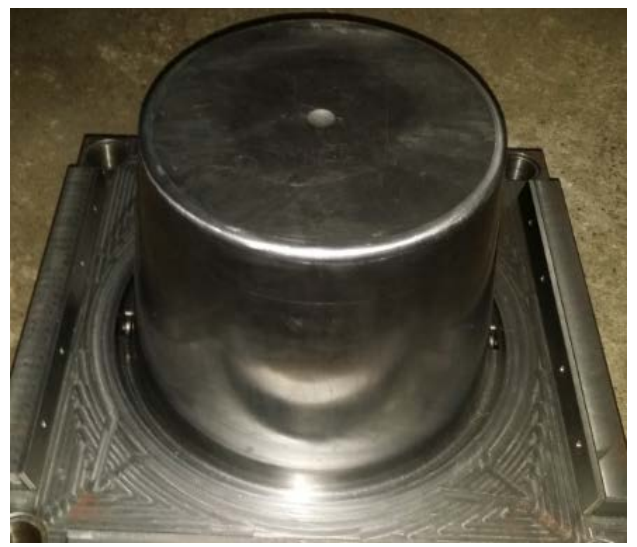

12. ábra. Összeszerelt 1-es és 2-es formalap

\section{Következtetések}

A vödörszerszám aktív részeinek az 1.2311 anyagból HSM stratégiákkal végzett megmunkálása után a kísérleti eredmények a következök:

-a HSM stratégiák és megfelelö szerszámok alkalmazásával a marási folyamatban fellépő erők jelentősen csökkennek, ami nagyobb sebességet és előtolást biztosít a folyamat számára;

-ilyen stratégiákkal a ciklusidő jelentősen csökken, ami pozitív hatással van a költségcsökkentésre;

-a felületi minőség lényegesen jobb összehasonlítva a klasszikus gyártási technológiákkal;

- a szerszám élettartama nő és az orsóterhelés csökken a HSM és a dinamikus marási stratégiákkal.

Összefoglalva megállapíthatjuk, hogy a HSM technológia használatával csökkenthetjük a megmunkálási ciklusidőt és a gyártási költségeket, növeljük a felület minőségét és a szerszám élettartamát. A legnagyobb jelentőséggel bíró hatása a környezetre van, mivel csökken az energiafogyasztás, az elhasznált szerszámok száma és a környezetszennyezés mértéke.

\section{Szakirodalmi hivatkozások}

[1] Begic-Hajdarevic, D., Cekic, A., Kulenovic, M.: Experimental Study on the High Speed Machining of Hardened Steel, Procedia Engineering 69, 2014, pg. 291-295.

[2] Cutting solutions by Ceratizit: Cutting tools, 2016, 1041-1043; 1067-1068.

[3] https://www.westyorkssteel.com/steelspecifications/werkstoff-standards/tool-steelw-nr/1-2311/ 